$\xi=$ 줄

\title{
A survey of knowledge about the MTA properties amongst internship students
}

\author{
Adnan Habib *, Mazen Doumani, Hossam Mossa, Ahmad Reda Bashnakli, Ali Nader Fathi Ibrahim
}

Department of Restorative Dental Sciences, Al-Farabi Colleges for Dentistry and Nursing, Riyadh, Saudi Arabia

*Corresponding author E-mail: adnanhabib71@hotmail.com

\begin{abstract}
Objective: The aim of this study was to assess the knowledge of the mineral trioxide aggregate (MTA) properties among internship students in Riyadh city, Saudi Arabia.

Methods: A standardized questionnaire comprised 14 multiple-choice questions about MTAproperties distributed to internship students in Riyadh city,Saudi Arabia. These questions contained types of MTA material, mechanical, chemical, physical properties of MTA, marginal adaptation and sealing ability, antibacterial properties, reaction with other dental materials, biocompatibility, and clinical performance. Data was coded computerized and analyzed using methods of descriptive statistics.

Results: The respondents of this questionnaire were 195 subjects. $51.5 \%$ of subjects confirmed that MTA sets in the presence of water. $69.4 \%$ of respondents confirmed that MTA is available as white and grey. Majority of subjects asserted the sealing ability (89.5\%) and antibacterial effects (71.6\%) of MTA material. The vast majority don't know the mixing time (50.6\%), and pH of MTA (52\%).

Conclusion: It has been observed an average knowledge about mineral trioxide aggregate (MTA), an increased knowledge about sealing ability and anti-bacterial effects , and poor knowledge about manipulation of MTA material amongst internship students .
\end{abstract}

Keywords: Biocompatibility; Mineral Trioxide Aggregate (MTA); Sealing Ability; Setting Time.

\section{Introduction}

Mineral trioxide aggregate (MTA) is a unique material with several interesting clinical applications. MTA has potential and one of the most multipurpose materials in last decades in the field of dentistry particularity in endodontic.

Mineral Trioxide Aggregate (MTA) was developed by Mohmoud Torabinejad at Loma Linda University, California, USA in 1993 and was awarded approval for endodontic use by the U.S. Food and Drug Administration in 1998(Lee SJ et al. 1994, Schwartz RS et al. 1999, Macwan C and Deshpande A 2014) . MTA is a powder made up of fine hydrophilic particles (Schwartz RS et al 1999, Schmitt D et al. 2001). Existing in tow types, Gray MTA (GMTA) and White MTA (WMTA), the two types are consisted of $75 \%$ Portland cement, $20 \%$ bismuth oxide, and 5\% gypsum (Ca) (Oliveira MG et al. 2007, Song JS et al. 2006). MTA is a mixture of a refined Portland cement and bismuth oxide (20\%) with small amounts of other mineral oxides (Rao A et al. 2009). Bismuth oxide is added to provide MTA materials with radiopacity. It has been shown that bismuth oxide affects calcium hydroxide sedimentation after MTA hydration; and bismuth oxide can be released in acidic conditions (inflammation) decreasing MTA's biocompatibility as it depresses cell multiplication (Camilleri J et al. 2009, Camilleri J 2007). According to earlier reports, gray MTA (GMTA) basically consists of tricalcium silicate, dicalcium silicate, tricalcium oxide, tricalcium aluminate, tetracalcium aluminoferrite, calcium sulphate, silicate oxide, and bismuth oxide(Song JS et al. 2006, Roberts HW et al. 2008), with a dominance of calcium and phosphorus ions(Torabinejad $\mathrm{M}$ et el. 1995). Later studies using electron probe microanalysis exhibited low-levels of phosphorus in MTA products (Sarkar NK et al. 1999, Asgary S et al. 2005). It has been shown that white MTA (WMTA) has lesser content of tetracalcium aluminoferrite component, iron, aluminium, and magnesium oxides (Sarkar NK et al. 1999, Song JS et al. 2006). MTA material has several advantages that widened its use in different fields of dentistry, and endodontics. Several in-vitro and in-vivo studies have shown hopeful results when MTA used as an endodontic material (Schmitt D et al. 2004, Torabinejad M and Chivian N 1999). It was primarily recommended as repair material for root perforations (Lee SJ et al. 1994). It was then widely used as a root-end filling material (Torabinejad M et al. 1993, Aqrabawi J 2000) and in direct pulp capping and pulpotomy of immature teeth with vital pulps (apexogenesis) (Torabinejad $\mathrm{M}$ and Chivian $\mathrm{N}$ 1999). In addition, because of its sealing ability, it was also suggested as an apical barrier in the treatment of teeth with opened apices and necrotic pulps (apexification) (Shabahang S and Torabinejad M 2000, Witherspoon DE and Ham K 2001) or coronal barrier for regenerative endodontics(Garcia-Godoy $\mathrm{F}$ and Murray PE 2012). It has been also suggested to use MTA as root canal sealer or as root canal filling material for the entire root canal system due to its good sealing ability and its property of setting with presence of moisture (Torabinejad M and Chivian N 1999, Vitti RP et al. 2013).

Knowledge of dental materials and their properties is essential for dental students and dentists to understand the rationale behind their use. Hence, the purpose of present survey study was to 
evaluate the knowledge about the mineral trioxide aggregate (MTA) properties among internship students in Riyadh, Saudi Arabia.

\section{Materials and methods}

This study took place in the department of restorative dental sciences, AlFarabi College for dentistry and nursing, Riyadh , Saudi Arabia between April and July 2017. This work was approved by the Research Ethics Committee in the university.

A standardized questionnaire distributed to internship students in three dental school in Riyadh city, Saudi Arabia. The questionnaire conducted for this study was a survey about the properties of mineral trioxide aggregate (MTA) material, the inclusion criterion in the study was every internship student in dental schools in Riyadh city whether was male or female. The questionnaire comprised 14 multiple-choice questions, and the participants were requested to answer these questions which contain gender of the student, types of MTA material, mechanical, chemical and physical properties of MTA, marginal adaptation and sealing ability, antibacterial properties, reaction with other dental materials, biocompatibility, and clinical performance. Data was coded computerized and analyzed using methods of descriptive statistics.

\section{Results}

The respondents of this questionnaire were 195 subjects from three dental schools in Riyadh city; $61 \%$ male and $39 \%$ female. $51.5 \%$ of subjects confirmed that MTA sets in the presence of water. $69.4 \%$ of respondents confirmed that MTA is available as white and grey. $52.6 \%$ of respondents don't know if grey MTA is more biocompatible than the white and $49.5 \%$ of respondents don't know the powder water ratio for MTA. Majority of subjects asserted the sealing ability $(89.5 \%)$ and antibacterial effects $(71.6 \%)$ of MTA material. While the vast majority don't know if MTA is not mutagenic and less cytotoxic than Super EBA and IRM $(58 \%)$, mixing time of MTA $(50.6 \%)$, and pH of MTA immediately after mixing and after setting. In terms of clinical performance $43 \%$ of respondents claimed that about $4 \mathrm{~mm}$ thickness of MTA ensure a good sealing, $46.3 \%$ of respondents confirmed that MTA didn't interfere or react with any material used to restore the tooth, whereas $54.7 \%$ of respondents didn't know if the set MTA release's calcium hydroxide when exposed to water. (All results from this questionnaire are shown in table 1).

Table 1: Show's Internship Student' Knowledge about MTA:

\begin{tabular}{|c|c|c|}
\hline \multicolumn{3}{|c|}{ 1. Gender } \\
\hline $39 \%$ Female & & $61 \%$ \\
\hline \multicolumn{3}{|c|}{ 2. MTA sets in the presence of water: } \\
\hline Yes: $51.5 \%$ & No $: 31.5 \%$ & I don't Know : 17\% \\
\hline \multicolumn{3}{|c|}{ 3. MTA is available as white and grey : } \\
\hline Yes: $69.4 \%$ & No $: 6.3 \%$ & I don't Know : $24.3 \%$ \\
\hline \multicolumn{3}{|c|}{ 4. Grey MTA is more biocompatible than the white: } \\
\hline Yes: $17.9 \%$ & No $: 29.5 \%$ & I don't Know : $52.6 \%$ \\
\hline \multicolumn{3}{|c|}{ 5. The powder water ratio for MTA should be $3: 1$} \\
\hline Yes:29.5\% & No $: 21 \%$ & I don't Know : $49.5 \%$ \\
\hline \multicolumn{3}{|c|}{6 . The set MTA ' when exposed to water ' releases calcium hydroxide } \\
\hline Yes: $36.4 \%$ & No : $18.9 \%$ & I don't Know : $54.7 \%$ \\
\hline \multicolumn{3}{|c|}{ 7. MTA has excellent sealing ability } \\
\hline Yes: $89.5 \%$ & No $: 0 \%$ & I don't Know : $10.5 \%$ \\
\hline
\end{tabular}

8. MTA has antibacterial effect especially against Enterococcus faecalis and Streptococcus sanguis

\begin{tabular}{|c|c|c|}
\hline Yes: $71.6 \%$ & No $: 10.5 \%$ & I don't Know : $17.9 \%$ \\
\hline \multicolumn{3}{|c|}{ 9.MTA is not mutagenic and less cytotoxic than Super EBA and IRM } \\
\hline Yes: $31.5 \%$ & No $: 10.5$ & I don't Know : $58 \%$ \\
\hline \multicolumn{3}{|c|}{ 10. Claimed that about $4 \mathrm{~mm}$ thickness of MTA ensure a good sealing } \\
\hline Yes: $43 \%$ & No : $21 \%$ & I don't Know : $36 \%$ \\
\hline \multicolumn{3}{|c|}{ 11. MTA mixing time should be less than 4 minutes } \\
\hline Yes: $31.5 \%$ & No : $17.5 \%$ & I don't Know :50.6\% \\
\hline \multicolumn{3}{|c|}{ 12. The setting time of grey MTA is 4 hours } \\
\hline Yes: $32.6 \%$ & No $: 25.2 \%$ & I don't Know : $24.2 \%$ \\
\hline \multicolumn{3}{|c|}{ 13. MTA didn't react or interfere with any other restorative material } \\
\hline Yes: $46.3 \%$ & No : $26.3 \%$ & I don't Know : $27.4 \%$ \\
\hline \multicolumn{3}{|c|}{$\begin{array}{c}\text { 14. MTA has a pH of } 10.2 \text { immediately after mixing and increase to } 12.5 \\
\text { after } 3 \text { hours }\end{array}$} \\
\hline Yes: $36.4 \%$ & No : $11.6 \%$ & I don't Know : $52 \%$ \\
\hline
\end{tabular}

\section{Discussion}

The development of (MTA) material by Torabinejad in 1993 was really an important event in dentistry and in endodontics, as this material clearly increased the success rate of several cases that used to have high failure rates. In dental literature, there is lacked of similar previous studies about general information that addressed the general knowledge on MTA.

MTA is available in two types based on the color known as gray and white MTA. Scanning electron microscopy (SEM) and electron probe microanalysis differentiated the differences between gray MTA and white MTA and revealed that the main differences are in the concentrations of $\mathrm{Al} 2 \mathrm{O} 3, \mathrm{MgO}$ and $\mathrm{FeO}$ (Sarkar NK et al. 2005). Most of the subjects $(69.4 \%)$ in this questionnaire confirmed that MTA is available as white and grey. Several investigators concluded that MTA is well tolerated by the tissues and biocompatible (Kettering JD and Torabinejad M 1995, Arens DE and Torabinejad M 1996, Sumer M et al. 2006). Kettering and Torabinejadin 1995 compared MTA with Super EBA and IRM and found that MTA is not mutagenic and less cytotoxic. There are conflicting with results in literature reports comparing the two types of MTA concerning biocompatibility and ability to induce hard tissue formation; some reports confirmed that the two MTA colors have similar cytotoxicity levels (Souza NJ et al. 2006, Koulaouzidou EA et al. 2008). Others showed that WMTA had higher in vitro toxicity than GMTA (Perez AL et al. 2003, Al-Haj Ali SN et al. 2014). The results from this questionnaire revealed that more than half $(52.6 \%)$ of respondents don't know if grey MTA is more biocompatible than the white.

It has been advocated that the powder water ratio for MTA should be 3:1(P:W) (Torabinejad M and Chivian N 1999, Schmitt D et al. 2001). Mixing can be done on a glass slab or on paper pad using a metal or plastic spatula to achieve putty like paste consistency. This mix should be covered with moistened cotton pellet to prevent dehydration of a mix. In this study $49.5 \%$ of respondents don't know the powder water ratio for MTA.

In terms of marginal adaptation and sealing ability $89.5 \%$ of subject in this survey confirmed the sealing ability of MTA and $43 \%$ of respondents claimed that about $4 \mathrm{~mm}$ thickness of MTA ensure a good sealing. It has been found that MTA is preferable to the other conventional root-end filling materials (Bates $\mathrm{CF}$ et al. 1996). And it was explained that MTA had been excellent sealing ability, which may occur because MTA expands during setting reaction (Shipper $\mathrm{G}$ et al. 2004, Torabinejad M et al. 2005). It was also found that about 4-mm thickness of MTA is sufficient to ensure a good sealing (Valois et al. 2004).

According to (Torabinejad et al. 1995) MTA showed no antimicrobial action against any of the anaerobes, but it did show a certain effect on facultative bacteria. It has claimed that MTA has the antibacterial effect especially against Enterococcus faecalis 
and Streptococcus sanguis(Al-Hazaimi et al. 2006). In present questionnaire $73.6 \%$ of respondents stated that MTA has an antibacterial effect, especially against E- faecalis and Streptococcus sanguis. Torabinejad et al. assured that the $\mathrm{pH}$ of set MTA is almost similar to calcium hydroxide. It has been found that immediately after mixing MTA has a pH of 10.2, after 3 hours of setting the $\mathrm{pH}$ increased to 12.5 (Torabinejad $\mathrm{M}$ et al. 1995). Only $36.4 \%$ of a respondent in this study affirmed the increase of $\mathrm{pH}$ value of MTA after setting.

In terms of manipulation of (MTA) it has been suggested that mixing time of MTA material should be less than four minutes (Sluyk SR et al. 1998). Torabinejad et al. found setting time about 2 hours and 45 minutes ( \pm 5 minutes) of grey MTA, while research done by Islam et al. revealed that initial setting time about 2 hours and 55 minutes and 2 hours and 20 minutes for grey MTA and white MTA, respectively(Islam I et al. 2006). In present survey half of a respondent don't know the mixing time of MTA, 24.2\% of a respondent don't know the setting time of MTA, and 51.5\% of subjects confirmed that MTA sets in the presence of water MTA is a powder composed of thin hydrophilic particles and requires moisture to set. During setting of MTA. Presence of moisture enhances the flexural strength of the set cement (Torabinejad M and Chivian N 1999). It has been found that MTA does not interfere or react with any other restorative material. When composite resins or GIC placed over MTA, it doesn't affect the setting reaction (Nandini S et al. 2007). On the other hand, it was claimed that residual calcium hydroxide may affect negatively in the adaptation of MTA to the dentinal wall. This results in reduced sealing ability, which occurs either by a mechanical obstacle of $\mathrm{CaOH} 2$ particle or by chemically reaction with MTA (Srinivasan $\mathrm{V}$ et al. 2009). The results from this survey revealed that only 26.3\% of subjects stated that MTA didn't interfere with restorative materials.

\section{Conclusion}

- An average knowledge about mineral trioxide aggregate (MTA) properties among internship students in Riyadh city has been observed.

- There has been increased knowledge about sealing ability and anti-bacterial effects of MTA material amongst internship students.

- There has been poor knowledge about manipulation of MTA material among internship students as the powder water ratio for MTA, mixing time, and setting time.

\section{Conflicts of interest}

There are no conflicts of interest

\section{Acknowledgements}

The authors wish to acknowledge the staff of AlFarabi colleges, particularly the staff of AlFarabi College for Dentistry and Nursing, Riyadh, Saudi Arabia.

\section{References}

[1] Lee SJ, Monsef M, Torabinejad M(1993) Sealing ability of a mineral trioxide aggregate for repair of lateral root perforations. Journal of Endodontics 19(11):541-4.https://doi.org/10.1016/S0099 2399(06)81282-3.

[2] Schwartz RS, Mauger M, Clement DJ, Walker WA 3rd (1999) Mineral trioxide aggregate: A new material for endodontics. The journal of the American Dental Association 130(7):967-75. https://doi.org/10.14219/jada.archive.1999.0337.

[3] Macwan C, Deshpande A(2014) Mineral trioxide aggregate (MTA) in dentistry: A review of literature. Journal of Oral Research and Review 6(2):71-74. https://doi.org/10.4103/2249-4987.152914.
[4] Schmitt D, Lee SJ, Bogen G(2001). Multifaceted use of ProRoot ${ }^{\mathrm{TM}}$ MTA root canal repair material. Journal of Pediatric Dentistry 23(4):326-330.

[5] Oliveira MG, Xavier CB, Demarco FF, Pinheiro AL, Costa AT, Pozza DH (2007) Comparative chemical study of MTA and Portland cements. Brazilian Dental Journal 18(1):3 7.https://doi.org/10.1590/S0103-64402007000100002.

[6] Song JS, Mante FK, Romanow WJ, Kim S(2006) Chemical analysis of powder and set forms of Portland cement, gray ProRoot MTA white Pro Root MTA, and gray MTA-Angelus. Oral Surgery, Oral Medicine, Oral Pathology, Oral Radiology, and Endodontology 102(6):809-815. https://doi.org/10.1016/j.tripleo.2005.11.034.

[7] Rao A, Rao A, Ramya Shenoy R (2009) Mineral trioxide aggregate - a review. The Journal of Clinical Pediatric Dentistry 34(1):1-8 https://doi.org/10.17796/jcpd.34.1.n1t0757815067g83.

[8] Camilleri J, Montesin FE, Papaioannou S, McDonald F, Pitt Ford TR (2004) Biocompatibility of two commercial forms of mineral trioxide aggregate. International Endodontic Journal 37(10):699704.https://doi.org/10.1111/j.1365-2591.2004.00859.x.

[9] CamilleriJ (2007) Hydration mechanisms of mineral trioxide aggregate. International Endodontic Journal 4(6):462-470 https://doi.org/10.1111/j.1365-2591.2007.01248.x.

[10] Roberts HW, Toth JM, Berzins DW, Charlton DG (2008) Mineral trioxide aggregate material use in endodontic treatment: a review of the literature. Dental Materials Journal 24(2):149164.https://doi.org/10.1016/j.dental.2007.04.007.

[11] Torabinejad M, Hong CU, McDonald F, Pitt Ford TR (1995) Physical and chemical properties of a new root-end filling material $\begin{array}{lll}\text { Journal of } & \text { Endodontics } & \text { 21(7):34-253 }\end{array}$ https://doi.org/10.1016/S0099-2399(06)80967-2.

[12] Asgary S, Parirokh M, Eghbal MJ, Brink F (2005) Chemical differences between white and gray mineral trioxide aggregate. Journal of Endodontics 31(2):101103.https://doi.org/10.1097/01.DON.0000133156.85164.B2.

[13] Sarkar NK, Caicedo R, Ritwik P, Moiseyeva R, Kawashima I. (2005) Physicochemical basis of the biologic properties of mineral trioxide aggregate. Journal of Endodontics; 31(2):97-100. https://doi.org/10.1097/01.DON.0000133155.04468.41.

[14] Torabinejad M, ChivianN (1999) Clinical applications of mineral trioxide aggregate. Journal of Endodontics 25(3):197205.https://doi.org/10.1016/S0099-2399(99)80142-3.

[15] Torabinejad M, Watson TF, Pitt Ford TR (1993) Sealing ability of a mineral trioxide aggregate when used as a root end $\neg$ filling material. Journal of Endodontics 19(12):591-95. https://doi.org/10.1016/S0099-2399(06)80271-2.

[16] AqrabawiJ (2000) sealing ability of amalgam, super EBA cement, and MTA when used as retrograde filling materials. British Dental Journal $11 ; 188(5): 266-8$.

[17] Shabahang S, Torabinejad M (2000) Treatment of teeth with open apices using mineral trioxide aggregate. Practical Periodontics and Aesthetic Dentistry $12(3): 315-20$; quiz 322.

[18] Witherspoon DE, Ham K (2001) One-visit apexification: technique for inducing root-end barrier formation in apical closures. Practical Periodontics and Aesthetic Dentistry 13:455-60; quiz 462.

[19] Garcia-Godoy F, Murray PE (2012) Recommendations for using regenerative endodontic procedures in permanent immature traumatized teeth. Dental Traumatology 28(1):33-41. https://doi.org/10.1111/j.1600-9657.2011.01044.x.

[20] Vitti RP, Prati C, Silva EJ, Sinhoreti MA, Zanchi CH, de Souza eSilva MG, et al(2013) Physical properties of MTA Fillapex sealer. $\begin{array}{llll}\text { Journal of } & \text { Endodontics }\end{array}$ https://doi.org/10.1016/j.joen.2013.04.015.

[21] Kettering JD, Torabinejad M (1995) Investigation of mutagenicity of mineral trioxide aggregate and other commonly used root-end filling materials. Journal of Endodontics 21(11):53742.https://doi.org/10.1016/S0099-2399(06)80980-5.

[22] Arens DE, Torabinejad M (1996) Repair of furcal perforations with mineral trioxide aggregate: Two case reports. Oral Surgery, Oral Medicine, Oral Pathology, Oral Radiology, and Endodontology $82(1): 84-8$

[23] Sumer M, Muglali M, Bodrumlu E, Guvenic T(2006) Reactions of connective tissue to amalgam, intermediate restorative material, mineral trioxide aggregate mixed with chlorhexidine. Journal of Endodontics32(11):1094-6. https://doi.org/10.1016/j.joen.2006.05.012.

[24] Souza NJ, Justo GZ, Oliveira CR, Haun M, Bincoletto C(2006) Cytotoxicity of materials used in perforation repair tested using the V79 fibroblast cell line and the granulocyte-macrophage progenitor 
cells. International Endodontic Journal. 39(1):407.https://doi.org/10.1111/j.1365-2591.2005.01045.x.

[25] Koulaouzidou EA, Economides N, Beltes P, Geromichalos G, Papazisis K(2008) In vitro evaluation of the cytotoxicity of ProRoot MTA and MTA Angelus. Journal of Oral Science 50(4):397-402. https://doi.org/10.2334/josnusd.50.397.

[26] Perez AL, Spears R, Gutmann JL, Opperman LA(2003) Osteoblasts and MG-63 osteosarcoma cells behave differently when in contact With ProRoot MTA And white MTA. International Endodontic Journal 36(8):564-70.https://doi.org/10.1046/j.13652591.2003.00691.x.

[27] Al-Haj Ali SN, Al-Jundi SH, Ditto DJ(2014) In vitro toxicity of grey MTA in comparison to white MTA on human periodontal ligament fibroblasts. European Archives of Paediatric Dentistry 15(6):429-33.https://doi.org/10.1007/s40368-014-0134-z.

[28] Bates CF, Carnes DL, Del Rio CE(1996) longitudinal sealing ability of mineral trioxide aggregate as a root-end filling material. $\begin{array}{lll}\text { Journal of } & \text { Endodontics } & \text { 22(11):575-8 }\end{array}$ https://doi.org/10.1016/S0099-2399(96)80023-9.

[29] Shipper G, Grossman ES, Botha AJ, Cleaton-Jones PE(2004) Marginal adaptation of mineral trioxide aggregate (MTA) compared with amalgam as a root-end filling material: A low vacuum (LV) versus high vacuum (HV) SEM study. International Endodontic Journal 37(5):325-36. https://doi.org/10.1111/j.01432885.2004.00806.x.

[30] Valois CR, Costa ED Jr(2004) Influence of the thickness of mineral trioxide aggregate on sealing ability of root-end filling in vitro. Oral Surgery, Oral Medicine, Oral Pathology, Oral Radiology, and Endodontology 97(1):108-11. https://doi.org/10.1016/S10792104(03)00359-7.

[31] Torabinejad M, Hong CU, Pitt Ford TR, Kettering JD (1995) Antibacterial effects of some root end filling materials. Journal of Endodontics 21(8):403-6.https://doi.org/10.1016/S00992399(06)80824-1.

[32] Al-Hezaimi K, Al-Shalan TA, Naghshbandi J, Oglesby S, Simon $\mathrm{JH}$, Rotstein I(2006) Antibacterial effect of two mineral trioxide aggregate (MTA) preparations against Enterococcus faecalis and Streptococcus sanguis in vitro. Journal of Endodontics 32(11):1053-6. https://doi.org/10.1016/j.joen.2006.06.004.

[33] Sluyk SR, Moon PC, Hartwell GR(1998) Evaluation of setting properties and retention characteristics of Mineral Trioxide Aggregate when used as a furcation perforation repair material. Journal of Endodontics 24(11):768-71. https://doi.org/10.1016/S00992399(98)80171-4.

[34] Islam I, Chng HK, Yap AU (2006) Comparison of the physical and mechanical properties of MTA and Portland cement. Journal of Endodontics 32(3):193-7.https://doi.org/10.1016/j.joen.2005.10.043.

[35] Nandini S, Ballal S, Kandaswamy D(2007) Influence of glass Ionomer cement on the interface and setting reaction of mineral trioxide aggregate when used as a furcal repair material using laser Raman spectroscopic analysis. Journal of Endodontics 33(2):16772.https://doi.org/10.1016/j.joen.2006.10.010.

[36] Srinivasan V, Waterhouse P, Whitworth J (2009) Mineral trioxide aggregate in paediatric dentistry. International Journal of Paediatric Dentistry19(1):34-47.https://doi.org/10.1111/j.1365-

263X.2008.00959.x. 